\title{
Mechanisms of hypothermia-induced cell protection in the brain
}

\author{
Katharina Rose Luise Schmitt ${ }^{*}$, Giang Tong ${ }^{1}$ and Felix Berger ${ }^{1,2}$
}

\begin{abstract}
Therapeutic hypothermia is an effective cytoprotectant and promising intervention shown to improve outcome in patients following cardiac arrest and neonatal hypoxia-ischemia. However, despite our clinical and experimental experiences, the protective molecular mechanisms of therapeutic hypothermia remain to be elucidated. Therefore, in this brief overview we discuss both the clinical evidence and molecular mechanisms of therapeutic hypothermia in order to provide further insights into this promising intervention.
\end{abstract}

Keywords: Hypothermia; Neuroprotection; RBM3; Anoxic injury; Inflammation

\section{Introduction}

Clinicians have investigated the application of therapeutic hypothermia on the human body for centuries. Increasing clinical evidence from meta-analysis of large randomized controlled trials and experimental data advocates the induction of therapeutic hypothermia as a tool to achieve neuroprotection [1]. Clinical indications for therapeutic hypothermia as a protection strategy include: myocardial infarction [2,3], cardiopulmonary bypass in adults [4], pediatric open heart surgery $[5,6]$, stroke [7], neonatal hypoxia-ischemia [8-10], and traumatic brain injury $[11,12]$.

To date, the strongest evidence for its efficacy exists for various clinical situations following cardiac arrest and neonatal hypoxia-ischemia. However, the effective application of hypothermia requires a thorough understanding of the injury mechanisms as well as its protective mechanisms. Therefore, we discuss in this brief overview both the clinical factors and molecular mechanisms of therapeutic hypothermia in order to provide further insights into this promising intervention.

\section{Review}

\section{Therapeutic hypothermia: clinical evidence}

Early experiences with therapeutic hypothermia in the 1940s thru 1960s falsely assumed that the protective effects were only due to the temperature-dependent reduction in

\footnotetext{
* Correspondence: katharina.schmitt@charite.de

${ }^{1}$ Department of Congenital Heart Disease/Pediatric Cardiology, German Heart Institute Berlin, Augustenburger Platz 1, 13353 Berlin, Germany Full list of author information is available at the end of the article
}

metabolism, which leads to lower oxygen and glucose demands [13]. Therefore, patients were routinely subjected to deep hypothermia $\left(<30^{\circ} \mathrm{C}\right)$ with varying durations ranging from 2 to 10 days [14]. Animal experiments in the 1980s led to the breakthrough discovery that using mild to moderate hypothermia $\left(31^{\circ} \mathrm{C}\right.$ to $\left.35^{\circ} \mathrm{C}\right)$ resulted in improved neurological outcome with fewer and less severe side effects [15]. More importantly, these findings led to the realization that hypothermia-induced neuroprotection is not only limited to decreased oxygen and glucose demands, but the mechanisms involved are indeed much more intricate.

Three large multicenter randomized studies of newborn infants with hypoxic ischemic encephalopathy suggest a beneficial effect in this patient population. Gluckman et al. demonstrated an improved outcome that persisted at 18 months of life in term infants suffering from moderate neonatal encephalopathy who were subjected to head cooling (CoolCap, Natus, San Carlos, CA, USA) for $72 \mathrm{~h}$ [10]. A second trial demonstrated whole-body cooling to $33.5^{\circ} \mathrm{C}$ for $72 \mathrm{~h}$ reduced the risk of mortality or moderate to severe disability in infants with moderate or severe encephalopathy surveyed at 18 to 22 months of age [16]. A third published Total Body Hypothermia for Neonatal Encephalopathy (TOBY) trial also showed benefits from similar whole-body cooling in newborns with perinatal asphyxia [17]. The study showed that hypothermia did not significantly reduce the rate of mortality or severe disability but resulted in improved neurologic outcomes in infants assessed at 18 months of age. However, the criteria for optimal candidates for therapeutic hypothermia have 
yet to be defined, and long-term follow-up (beyond 18 months of age) to assess the persistent and lifelong benefits are needed.

Current investigations also include the Infant Cooling Evaluation (ICE) trial to investigate the effect of moderate whole-body hypothermia to $33.5^{\circ} \mathrm{C}$ for $72 \mathrm{~h}$ in newborns with HIE [18] and the Therapeutic Hypothermia after Pediatric Cardiac Arrest (THAPCA) trials, a 30-site randomized clinical trial investigating the effectiveness of therapeutic hypothermia versus therapeutic normothermia after in-hospital (THAPCA-IH) or out-of-hospital (THAPCA-OH) cardiac arrest in children $[19,20]$.

\section{Clinical issues}

Clinical issues regarding optimal target temperature, rate of cooling, duration of cooling, rate of rewarming, as well as optimal treatment window need further investigation. With the introduction of therapeutic hypothermia, it is important to differentiate between the 'induction phase', when the temperature drops; the 'maintenance phase', when the target temperature is achieved and maintained at the desired level; and the 'rewarming phase', when the patient is slowly rewarmed back to normothermia.

Hypothermia induces stress responses, such as shivering, that result in increased oxygen consumption and metabolic rate in non-sedated patients. Animal experiments suggest that the neuroprotective effects of hypothermia are negated if cooling is used on non-sedated animals [21,22]. Other side effects include increased risk of infection, cold diuresis and hypovolemia, electrolyte disorders, insulin resistance, impaired drug clearance, and mild coagulopathy [15].

\section{Therapeutic hypothermia: molecular mechanisms}

Therapeutic hypothermia-induced cellular protection against anoxic brain injury is a global process affecting multiple molecular and cellular mechanisms. Cooling results in a $6 \%$ to $10 \%$ decrease in cerebral metabolism for every $1^{\circ} \mathrm{C}$ reduction in body temperature [23]. Therefore, a thorough understanding of the underlying mechanisms of protection induced by therapeutic hypothermia is vital for designing appropriate and effective treatments. Insufficient knowledge of the physiological changes and side effects that occur during mild $\left(34^{\circ} \mathrm{C}\right.$ to $\left.35.9^{\circ} \mathrm{C}\right)$, moderate $\left(32^{\circ} \mathrm{C}\right.$ to $\left.33.9^{\circ} \mathrm{C}\right)$, moderate-deep $\left(30^{\circ} \mathrm{C}\right.$ to $\left.31.9^{\circ} \mathrm{C}\right)$, and deep $\left(<30^{\circ} \mathrm{C}\right)$ hypothermia is likely to lead to lower therapeutic efficacy or even failure of treatment [15].

Ischemic brain injury, reperfusion injury, and secondary brain damage are the three main categories of temperaturedependent injury processes that can be effectively mitigated by mild to moderate hypothermia. Due to the broad effects of hypothermia, it is more clinically effective than treatments that focus on blocking just one of these processes.

Variable factors such as type of injury (traumatic versus pure ischemia) and patient physiology (genetic factors, age, gender, etc.) all contribute to the complicated injury processes. Although the window of opportunity to initiate hypothermic treatment as well as the duration of cooling to achieve full efficacy may vary, the success or failure of therapeutic hypothermia treatment is dependent on the following four key factors $[24,15]$ :

1. Rate of cooling - rapid initiation of cooling immediately after injury resulted in better outcomes in animal studies. A concept summarized by the phrase 'time is brain'.

2. Duration of cooling - dependent of severity of injury and the time allotted to achieve target temperature.

3. Rate of rewarming - slow rewarming is critical to not reactivate initial injury processes.

4. Management and prevention of side effects.

\section{Apoptosis and mitochondrial dysfunction}

Ischemia/reperfusion injuries can lead to cellular necrosis or apoptosis, also referred to as programmed cell death. The development of apoptosis is dependent on several cellular processes, including mitochondria dysfunction, activation of caspase enzymes, and other cellular energy metabolism disorders. Hypothermia has been observed to affect almost all of these injury processes, thereby preventing the initiation or interrupting the early stages of the apoptotic pathway [25]. The window of opportunity to initiate therapeutic hypothermia to mitigate apoptosis after anoxia is broad, as apoptosis begins relatively late and continues for a long duration. Therefore, mitigating the effects of these injury processes of the apoptotic pathway is a viable treatment for neuroprotection in patients.

Interrupted blood supply to the brain causes an immediate reduction in ATP and phosphocreatine, initiating a switch in intracellular metabolism to anaerobic glycolysis [26]. As a result, intracellular levels of inorganic phosphate, lactate, and $\mathrm{H}^{+}$are dramatically increased, leading to both intracellular and extracellular acidosis and calcium $\left(\mathrm{Ca}^{2+}\right)$ influx into the cells [27]. To further exacerbate the injury process, acidosis and the lack of ATP inhibit cellular mechanisms normally responsible for controlling excessive intracellular $\mathrm{Ca}^{2+}$, such as ATP-dependent $\mathrm{Na}^{+} / \mathrm{K}^{+}$ pumps and $\mathrm{Na}^{+}, \mathrm{K}^{+}$, and $\mathrm{Ca}^{+}$channels [28]. The excess influx of $\mathrm{Ca}^{2+}$ eventually leads to mitochondria dysfunction and activation of the caspase-9 intrinsic apoptotic pathway. Data from experimental studies have proven that hypothermia has a beneficial impact on the ion pump dysfunction and reduces the influx of calcium into the cells, thereby decreasing neurotoxicity $[28,29]$.

\section{Inflammation}

Ischemia/reperfusion injury stimulates innate immune responses, which can lead to secondary brain injury. It 
triggers the release of pro-inflammatory cytokines (i.e. IL-1 $\beta$, TNF $\alpha$, and IL-6) [30], the chemokine MCP1 [31] and pro-inflammatory mediators (ROS and NOS) in microglia, and circulating leukocytes [32]. Hypothermia attenuates many aspects of this pro-inflammatory immune response, but it also reduces the expression of some anti-inflammatory cytokines (IL-10 and TGF $\beta$ ) [33]. Animal studies showed controversial effects of hypothermia on NF- $\mathrm{kB}$, a transcription factor that plays a central role in regulating the inflammatory responses [34-37]. Yenari et al. showed that mild hypothermia decreased NF- $\mathrm{BB}$ translocation and activation in rodents [37]. In contrast to Fairchild et al. who showed in cell culture studies after moderate hypothermia a prolonged accumulation of NF- $\mathrm{kB}$ in the nucleus. These findings were explained with a delayed phosphorylation of $\mathrm{IK} B \alpha$, the cytosolic inhibitory protein of NF-kB. The Janus kinase (JAK) and signal transducer and activator of transcription pathway (STAT) is a common signaling pathway used by many cytokines. Ischemia leads to a JAK2 and STAT3 activation mediated by IL-6. Inhibiting this pathway resulted in a decreased number of apoptotic cells [34]. Mild hypothermia attenuates STAT3 expression which might be a possible mechanism of hypothermiainduced neuroprotection [38].

\section{Blood-brain barrier disruption}

Mild to moderate hypothermia has been shown to significantly reduce blood-brain barrier disruptions following ischemia-reperfusion injury by decreasing vascular permeability, resulting in decreased edema formation [39-41]. Specifically, hypothermia suppresses the activation of matrix metalloproteinases (MMPs) responsible for degradation of the extracellular matrix while increasing the expression of endogenous MMP inhibitors, such as metalloproteinase inhibitor 2 (TIMP2) [42]. As a result, the structural proteins and cells that constitute the $\mathrm{BBB}$ are preserved and the opening of water channels is prevented.

\section{Free radical production}

The inflammatory response induced by ischemia/reperfusion injury usually coincides with the production of free oxygen radicals such as superoxide $\left(\mathrm{O}_{2}^{-}\right)$, peroxynitrite $\left(\mathrm{NO}_{2}^{-}\right)$, hydrogen peroxide $\left(\mathrm{H}_{2} \mathrm{O}_{2}\right)$, and hydroxyl radicals $\left(\mathrm{OH}^{-}\right)$[43]. The extent of free radical production following ischemia/reperfusion is so large that protective cellular antioxidant mechanisms are overwhelmed, resulting in peroxidation of lipids, proteins, and nucleic acids [27]. Although hypothermia cannot completely diminish free radical production in injured cells, it can significantly reduce the amount of free radicals enough to allow for the endogenous antioxidant mechanisms to mitigate the oxidative damage. In addition, the suppression of free radical production has been observed to be linearly proportional to the decrease in temperature [28].

\section{Rescue gene RBM3}

Although hypothermia reduces cellular metabolism and down-regulates global protein synthesis in mammalian cells, a small subset of cold-shock proteins are induced by low temperature. RNA-binding motif protein 3 (RBM3), a member of the glycine-rich RNA-binding protein (GRP) family, is one of the first proteins synthesized in response to hypothermia [44] and hypoxia [45]. Additionally, RBM3 expression is elevated in response to NMDA-type glutamate receptor activation [46]. Mild hypothermia is sufficient to induce the expression of RBM3 [44], while elevated temperature has been shown to suppress RBM3 expression [47]. We observed that RBM3 expression is induced by moderate hypothermia $\left(33.5^{\circ} \mathrm{C}\right)$ in murine organotypic hippocampal slice cultures (OHSCs) and hippocampal neurons (HT-22), but not by deep hypothermia $\left(17^{\circ} \mathrm{C}\right)$ nor in microglia cells (BV-2) at both cooling temperatures [48].

Although many studies on RBM3 have been focused on their regulation in non-neuronal cells in response to hypothermia and other stress factors [44], there is growing interest in their role as effectors in therapeutic hypothermia-induced neuroprotection. RBM3 is widely expressed during the early stages of brain development, especially in the first to second postnatal weeks, where it is dynamically regulated [49]. Recent studies have concluded that RBM3 has anti-apoptotic functions and can enhance cell proliferation [50]. RBM3 is induced by hypoxia independent of HIF-1 [45], which itself is suppressed by mild hypothermia [51]. Furthermore, RBM3 has been shown to play a major role in promoting translation in neuronal cells, and recently, RBM3 up-regulation in neuronal cells in response to hypothermia has been implicated in hypothermia-induced neuroprotection [52].

\section{Drug-induced hypothermia}

Drug-induced hypothermia may serve as an alternative to physical hypothermia, which can be technically tedious to apply and may cause serious side effects. Animal studies have shown that hypothermia is induced by synthetic cannabinoid CB1 agonists WIN55212-2 and HU210. Intramuscular injection of WIN55212-2 induced rapid and prolonged hypothermia in a dose-dependent manner in rats [53], and HU-210 was observed to be protective against ischemic damage by reducing infarct volumes and motor dysfunction [54]. In the same study, HU-210 injected after ischemic onset resulted in deeper and lengthier hypothermia.

\section{Conclusions}

Temperature management continues to play an important role in the treatment of patients suffering from neurological injuries. Therapeutic hypothermia and it's proven ability to attenuate post-ischemic injury represents a quantum leap in the clinical setting [15], but more work is 
needed, particularly in infants and children suffering from asphyxial cardiac arrest. Additionally, the induced hypothermic effects of cannabinoid CB1 receptor agonists, WIN55212-2 and HU-210, as alternatives to or in combination with therapeutic hypothermia also warrant further investigation. The full beneficial effect of cooling remains to be discovered as we optimize the process by expanding our knowledge of the basic mechanisms, verify the treatment windows, and improve the cooling and monitoring devices in the coming years.

\section{Competing interests}

The authors declare that they have no competing interests.

\section{Authors' contributions}

KRLS and GT contributed equally to the drafting of this manuscript. FB edited the manuscript and gave the final approval of the version to be published. All authors read and approved the final manuscript.

\section{Acknowledgments}

We thank Sylvia Wowro for proofreading the manuscript.

\section{Author details}

${ }^{1}$ Department of Congenital Heart Disease/Pediatric Cardiology, German Heart Institute Berlin, Augustenburger Platz 1, 13353 Berlin, Germany. ²Department of Pediatric Cardiology, Charité Universitätsmedizin Berlin, Campus Virchow-Klinikum, Augustenburger Platz 1, 13353 Berlin, Germany.

\section{Received: 31 March 2014 Accepted: 27 August 2014}

Published online: 01 December 2014

\section{References}

1. Drury PP, Gunn ER, Bennet L, Gunn AJ (2014) Mechanisms of hypothermic neuroprotection. Clin Perinatol 41(1):161-175. doi:10.1016/j.clp.2013.10.005

2. Holzer M, Behringer W (2008) Therapeutic hypothermia after cardiac arrest and myocardial infarction. Best Pract Res Clin Anaesthesiol 22(4):711-728

3. Oommen SS, Menon V (2011) Hypothermia after cardiac arrest: beneficial, but slow to be adopted. Cleve Clin J Med 78(7):441-448. doi:10.3949/ ccjm.78a.10157

4. Svensson LG, Crawford ES, Hess KR, Coselli JS, Raskin S, Shenaq SA, Safi HJ (1993) Deep hypothermia with circulatory arrest. Determinants of stroke and early mortality in 656 patients. J Thorac Cardiovasc Surg 106(1):19-28, discussion 28-31

5. Bellinger DC, Wypij D, Kuban KC, Rappaport LA, Hickey PR, Wernovsky G, Jonas RA, Newburger JW (1999) Developmental and neurological status of children at 4 years of age after heart surgery with hypothermic circulatory arrest or low-flow cardiopulmonary bypass. Circulation 100(5):526-532

6. International Liaison Committee on R (2005) 2005 international consensus on cardiopulmonary resuscitation and emergency cardiovascular care science with treatment recommendations. Part 6: paediatric basic and advanced life support. Resuscitation 67(2-3):271-291. doi:10.1016/j. resuscitation.2005.09.020

7. Maier CM, Ahern K, Cheng ML, Lee JE, Yenari MA, Steinberg GK (1998) Optimal depth and duration of mild hypothermia in a focal model of transient cerebral ischemia: effects on neurologic outcome, infarct size, apoptosis, and inflammation. Stroke 29(10):2171-2180

8. Eicher DJ, Wagner CL, Katikaneni LP, Hulsey TC, Bass WT, Kaufman DA, Horgan MJ, Languani S, Bhatia JJ, Givelichian LM, Sankaran K, Yager JY (2005) Moderate hypothermia in neonatal encephalopathy: efficacy outcomes. Pediatr Neurol 32(1):11-17. doi:10.1016/j. pediatrneurol.2004.06.014

9. Edwards AD, Azzopardi DV (2006) Therapeutic hypothermia following perinatal asphyxia. Arch Dis Child Fetal Neonatal Ed 91(2):F127-F131. doi:10.1136/adc.2005.071787

10. Gluckman PD, Wyatt JS, Azzopardi D, Ballard R, Edwards AD, Ferriero DM, Polin RA, Robertson CM, Thoresen M, Whitelaw A, Gunn AJ (2005) Selective head cooling with mild systemic hypothermia after neonatal encephalopathy: multicentre randomised trial. Lancet 365(9460):663-670. doi:10.1016/S0140-6736(05)17946-X

11. Marion DW, Penrod LE, Kelsey SF, Obrist WD, Kochanek PM, Palmer AM, Wisniewski SR, DeKosky ST (1997) Treatment of traumatic brain injury with moderate hypothermia. N Engl J Med 336(8):540-546. doi:10.1056/ NEJM199702203360803

12. Li P, Yang C (2014) Moderate hypothermia treatment in adult patients with severe traumatic brain injury: a meta-analysis. Brain Inj 28(8):1036-1041. doi:10.3109/02699052.2014.910609

13. Fay $T$ (1959) Early experiences with local and generalized refrigeration of the human brain. J Neurosurg 16(3):239-259. doi:10.3171/jns.1959.16.3.0239, discussion 259-260

14. Shulman K, Rosomoff HL (1959) Effect of hypothermia on mortality in experimental injury to the brain. Am J Surg 98:704-705

15. Polderman KH (2009) Mechanisms of action, physiological effects, and complications of hypothermia. Crit Care Med 37(7 Suppl):S186-S202. doi:10.1097/CCM.0b013e3181aa5241

16. Shankaran S, Laptook AR, Ehrenkranz RA, Tyson JE, McDonald SA, Donovan EF, Fanaroff AA, Poole WK, Wright LL, Higgins RD, Finer NN, Carlo WA, Duara S, Oh W, Cotten CM, Stevenson DK, Stoll BJ, Lemons JA, Guillet R, Jobe AH, National Institute of Child H, Human Development Neonatal Research N (2005) Whole-body hypothermia for neonates with hypoxic-ischemic encephalopathy. N Engl J Med 353(15):1574-1584. doi:10.1056/ NEJMcps050929

17. Azzopardi DV, Strohm B, Edwards AD, Dyet L, Halliday HL, Juszczak E, Kapellou O, Levene M, Marlow N, Porter E, Thoresen M, Whitelaw A, Brocklehurst P, Group TS (2009) Moderate hypothermia to treat perinatal asphyxial encephalopathy. N Engl J Med 361(14):1349-1358. doi:10.1056/ NEJMoa0900854

18. Jacobs SE, Morley CJ, Inder TE, Stewart MJ, Smith KR, McNamara PJ, Wright IM, Kirpalani HM, Darlow BA, Doyle LW, Infant Cooling Evaluation C (2011) Whole-body hypothermia for term and near-term newborns with hypoxic-ischemic encephalopathy: a randomized controlled trial. Arch Pediatr Adolesc Med 165(8):692-700. doi:10.1001/archpediatrics.2011.43

19. Pemberton VL, Browning B, Webster A, Dean JM, Moler FW (2013) Therapeutic hypothermia after pediatric cardiac arrest trials: the vanguard phase experience and implications for other trials. Pediatr Crit Care Med 14(1):19-26. doi:10.1097/PCC.0b013e31825b860b

20. Moler FW, Silverstein FS, Meert KL, Clark AE, Holubkov R, Browning B, Slomine BS, Christensen JR, Dean JM (2013) Rationale, timeline, study design, and protocol overview of the therapeutic hypothermia after pediatric cardiac arrest trials. Pediatr Crit Care Med 14(7):e304-e315. doi:10.1097/PCC.0b013e31828a863a

21. Thoresen M, Satas S, Loberg EM, Whitelaw A, Acolet D, Lindgren C, Penrice J, Robertson N, Haug E, Steen PA (2001) Twenty-four hours of mild hypothermia in unsedated newborn pigs starting after a severe global hypoxic-ischemic insult is not neuroprotective. Pediatr Res 50(3):405-411. doi:10.1203/00006450-200109000-00017

22. Tooley JR, Satas S, Porter H, Silver IA, Thoresen M (2003) Head cooling with mild systemic hypothermia in anesthetized piglets is neuroprotective. Ann Neurol 53(1):65-72. doi:10.1002/ana.10402

23. Hagerdal M, Harp J, Nilsson L, Siesjo BK (1975) The effect of induced hypothermia upon oxygen consumption in the rat brain. J Neurochem 24(2):311-316

24. Lampe JW, Becker LB (2011) State of the art in therapeutic hypothermia Annu Rev Med 62:79-93. doi:10.1146/annurev-med-052009-150512

25. Xu L, Yenari MA, Steinberg GK, Giffard RG (2002) Mild hypothermia reduces apoptosis of mouse neurons in vitro early in the cascade. J Cereb Blood Flow Metab 22(1):21-28. doi:10.1097/00004647-200201000-00003

26. Small DL, Morley P, Buchan AM (1999) Biology of ischemic cerebral cell death. Prog Cardiovasc Dis 42(3):185-207

27. Belch JJ (1992) Free radicals and their scavenging in stroke. Scott Med J 37(3):67-68

28. Hall ED (1997) Brain attack. Acute therapeutic interventions. Free radical scavengers and antioxidants. Neurosurg Clin N Am 8(2):195-206

29. Siesjo BK, Bengtsson F, Grampp W, Theander S (1989) Calcium, excitotoxins, and neuronal death in the brain. Ann N Y Acad Sci 568:234-251

30. Wang Q, Tang XN, Yenari MA (2007) The inflammatory response in stroke. J Neuroimmunol 184(1-2):53-68. doi:10.1016/j.jneuroim.2006.11.014

31. Meybohm P, Gruenewald M, Zacharowski KD, Albrecht M, Lucius R, Fosel N, Hensler J, Zitta K, Bein B (2010) Mild hypothermia alone or in combination 
with anesthetic post-conditioning reduces expression of inflammatory cytokines in the cerebral cortex of pigs after cardiopulmonary resuscitation. Crit Care 14(1):R21. doi:10.1186/Cc8879

32. Perrone S, Szabo M, Bellieni CV, Longini M, Bango M, Kelen D, Treszl A, Negro S, Tataranno ML, Buonocore G (2010) Whole body hypothermia and oxidative stress in babies with hypoxic-ischemic brain injury. Pediatr Neurol 43(4):236-240. doi:10.1016/j.pediatrneurol.2010.05.009

33. Matsui T, Kakeda T (2008) IL-10 production is reduced by hypothermia but augmented by hyperthermia in rat microglia. J Neurotrauma 25(6):709-715. doi:10.1089/neu.2007.0482

34. Fairchild KD, Singh IS, Carter HC, Hester L, Hasday JD (2005) Hypothermia enhances phosphorylation of I\{kappa\}B kinase and prolongs nuclear localization of NF-\{kappa\}B in lipopolysaccharide-activated macrophages. Am J Physiol Cell Physiol 289(5):22

35. Gibbons H, Dragunow M (2006) Microglia induce neural cell death via a proximity-dependent mechanism involving nitric oxide. Brain Res 1084:1-15

36. Han HS, Karabiyikoglu M, Kelly S, Sobel RA, Yenari MA (2003) Mild hypothermia inhibits nuclear factor-[kgr]B translocation in experimental stroke. J Cereb Blood Flow Metab 23(5):589-598

37. Webster CM, Kelly S, Koike MA, Chock VY, Giffard RG, Yenari MA (2009) Inflammation and NF[kappa]B activation is decreased by hypothermia following global cerebral ischemia. Neurobiol Dis 33(2):301-312. doi:10.1016/j.nbd.2008.11.001

38. Choi JS, Park J, Suk K, Moon C, Park YK, Han HS (2011) Mild hypothermia attenuates intercellular adhesion molecule-1 induction via activation of extracellular signal-regulated kinase-1/2 in a focal cerebral ischemia model. Stroke Res Treat 2011:846716. doi:10.4061/2011/846716

39. Huang ZG, Xue D, Preston E, Karbalai H, Buchan AM (1999) Biphasic opening of the blood-brain barrier following transient focal ischemia: effects of hypothermia. Can J Neurol Sci 26(4):298-304

40. Jurkovich GJ, Pitt RM, Curreri PW, Granger DN (1988) Hypothermia prevents increased capillary permeability following ischemia-reperfusion injury. J Surg Res 44(5):514-521

41. Lee JE, Yoon YJ, Moseley ME, Yenari MA (2005) Reduction in levels of matrix metalloproteinases and increased expression of tissue inhibitor of metalloproteinase-2 in response to mild hypothermia therapy in experimental stroke. J Neurosurg 103(2):289-297. doi:10.3171/jns.2005.103.2.0289

42. Baumann E, Preston E, Slinn J, Stanimirovic D (2009) Post-ischemic hypothermia attenuates loss of the vascular basement membrane proteins, agrin and SPARC, and the blood-brain barrier disruption after global cerebral ischemia. Brain Res 1269:185-197. doi:10.1016/j.brainres.2009.02.062

43. Globus MY, Alonso O, Dietrich WD, Busto R, Ginsberg MD (1995) Glutamate release and free radical production following brain injury: effects of posttraumatic hypothermia. J Neurochem 65(4):1704-1711

44. Danno S, Nishiyama H, Higashitsuji H, Yokoi H, Xue JH, Itoh K, Matsuda T, Fujita J (1997) Increased transcript level of RBM3, a member of the glycine-rich RNA-binding protein family, in human cells in response to cold stress. Biochem Biophys Res Commun 236(3):804-807. doi:10.1006/ bbrc.1997.7059

45. Wellmann S, Buhrer C, Moderegger E, Zelmer A, Kirschner R, Koehne P, Fujita J, Seeger K (2004) Oxygen-regulated expression of the RNA-binding proteins RBM3 and CIRP by a HIF-1-independent mechanism. J Cell Sci 117 (Pt 9):1785-1794. doi:10.1242/jcs.01026

46. Hsu HK, Shao PL, Tsai KL, Shih HC, Lee TY, Hsu C (2005) Gene regulation by NMDA receptor activation in the SDN-POA neurons of male rats during sexual development. J Mol Endocrinol 34(2):433-445. doi:10.1677/ jme.1.01601

47. Zeng Y, Kulkarni P, Inoue T, Getzenberg RH (2009) Down-regulating cold shock protein genes impairs cancer cell survival and enhances chemosensitivity. J Cell Biochem 107(1):179-188. doi:10.1002/jcb.22114

48. Tong G, Endersfelder S, Rosenthal LM, Wollersheim S, Sauer IM, Buhrer C, Berger F, Schmitt KR (2013) Effects of moderate and deep hypothermia on RNA-binding proteins RBM3 and CIRP expressions in murine hippocampal brain slices. Brain Res 1504:74-84. doi:10.1016/j.brainres.2013.01.041

49. Pilotte J, Cunningham BA, Edelman GM, Vanderklish PW (2009) Developmentally regulated expression of the cold-inducible RNA-binding motif protein 3 in euthermic rat brain. Brain Res 1258:12-24. doi:10.1016/j.brainres.2008.12.050

50. Wellmann S, Zelmer A, Nitsch C, Bucher HU, Buhrer C (2010) The Rnabinding protein $\mathrm{RBM} 3$ is involved in hypothermia induced neuroprotection. Pediatr Res 68:101-102
51. Tanaka T, Wakamatsu T, Daijo H, Oda S, Kai S, Adachi T, Kizaka-Kondoh S, Fukuda K, Hirota K (2010) Persisting mild hypothermia suppresses hypoxia-inducible factor-1 alpha protein synthesis and hypoxia-inducible factor-1-mediated gene expression. Am J Physiol Regul Integr Comp Physiol 298(3):R661-R671. doi:10.1152/ajpregu.00732.2009

52. Chip S, Zelmer A, Ogunshola OO, Felderhoff-Mueser U, Nitsch C, Buhrer C, Wellmann S (2011) The RNA-binding protein RBM3 is involved in hypothermia induced neuroprotection. Neurobiol Dis 43(2):388-396. doi:10.1016/j.nbd.2011.04.010

53. Rawls SM, Cabassa J, Geller EB, Adler MW (2002) CB1 receptors in the preoptic anterior hypothalamus regulate WIN 55212-2 [(4,5-dihydro-2-methyl-4 (4-morpholinylmethyl)-1-(1-naphthalenyl-carbonyl)-6H-pyrrolo[3,2,1ij]quinolin-6one]-induced hypothermia. J Pharmacol Exp Ther 301(3):963-968

54. Leker RR, Gai N, Mechoulam R, Ovadia H (2003) Drug-induced hypothermia reduces ischemic damage: effects of the cannabinoid HU-210. Stroke 34(8):2000-2006. doi:10.1161/01.STR.0000079817.68944.1E

doi:10.1186/s40348-014-0007-x

Cite this article as: Schmitt et al:: Mechanisms of hypothermia-induced cell protection in the brain. Molecular and Cellular Pediatrics 2014 1:7.

\section{Submit your manuscript to a SpringerOpen ${ }^{\odot}$ journal and benefit from:}

- Convenient online submission

- Rigorous peer review

- Immediate publication on acceptance

- Open access: articles freely available online

- High visibility within the field

- Retaining the copyright to your article

Submit your next manuscript at $>$ springeropen.com 